A C G

publications

Rec. Nat. Prod. 13:4 (2019) 333-345

records of natural

products

\title{
Assessment of Endemic Cota fulvida (Asteraceae) for Phytochemical Composition and Inhibitory Activities against Oxidation, $\alpha$-Amylase, Lipoxygenase, Xanthine Oxidase and Tyrosinase Enzymes
}

\section{Gulmira Özek® 1*, M. Ufuk Özbek ${ }^{\circledR 2}$, Suleyman Yur ${ }^{\circledR}$, Fatih Göger 1,3, Munevver Arslan ${ }^{4}$ and Temel Özek $\odot 1,3$}

${ }^{1}$ Department of Pharmacognosy, Faculty of Pharmacy, Anadolu University, 26470, Eskisehir, Türkiye

${ }^{2}$ Department of Biology, Faculty of Science, Gazi University, 06500, Teknikokullar, Ankara, Türkiye

${ }^{3}$ Medicinal Plant, Drug and Scientific Research Center (AUBIBAM), Anadolu University, 26470 Eskisehir, Türkiye

${ }^{4}$ Research Institute for Forest Soil and Ecology, P.o.Box. 61, 26160, Eskişehir, Türkiye

(Received September 04, 2018; Revised October 28, 2018; Accepted October 29, 2018)

\begin{abstract}
In the present work, chemical compositions of essential oil and methanol extract of endemic Cota fulvida (Grierson) Holub were investigated as well as their antioxidant, antidiabetic, antiinflammatory and antimelanogenesis potent. The phytochemical analyses have been performed with GC-MS/FID and LC-MS/MS techniques. The essential oil was characterized with hexadecanoic acid $(25.6 \%)$, camphor $(6.1 \%)$, caryophyllene oxide $(5.3 \%), 1,8$-cineole $(4.9 \%)$ and humulene epoxide $(3.9 \%)$. In the extract, phenolic acids, phenylpropanoid dimer and flavonoids were detected. The major constituents of the extracts were found to be 5-feruloylquinic acid, caftaric acid, 3,5-Odicafeoylquinic acid and quercetin rutinoside. The antioxidant activities of the oil and extract were evaluated through scavenging of free radicals, inhibition of linoleic acid peroxidation and superoxide anion radical $\left(\mathrm{O}^{2-}\right)$ generated by xanthine - xanthine oxidase (XO) system. The extract showed free radical scavenging activity $\left(\mathrm{IC}_{50} 0.131 \mathrm{mg} / \mathrm{mL}\right.$ ), Trolox equivalent antioxidant capacity $(1.33 \mathrm{mM})$ and inhibited (Inh. $36.3 \%)$ peroxidation of lipids. The oil and extract demonstrated significant hypoglycemic activity via inhibition of porcine pancreatic $\alpha$-amylase. The antiinflammatory effects of the oil and extract via inhibition of 5-LOX enzyme were found as $53.7 \%$ and $23.9 \%$, respectively. The extract demonstrated moderate inhibitory effect $(23.3 \%)$ on oxidation of L-DOPA via inhibition of tyrosinase enzyme.
\end{abstract}

Keywords: Cota fulvida; essential oil; extract; GC-MS/FID; LC-MS/MS; activity. (C) 2019 ACG Publications. All rights reserved.

\section{Introduction}

The genus Cota J. Gay is represented by 63 taxa in the world and is mainly distributed in Europe (excluding northern Europe), North Africa, Caucasia and Central Asia [1]. Cota was earlier classified as a section in the genus Anthemis L. in Flora of Turkey [2]. According to the last reports, the Anthemis section Cota has been accepted as a generic name, Cota $[3,4]$. In Turkey, the genus consists of 22 taxa, nine of which are endemic [5]. Recently, a new species Cota hamzaoglui Özbek \& Vural has been described [1].

\footnotetext{
* Corresponding author. E-mail: gulmiraozek@gmail.com; Phone: +90-222-3350580 Fax:+90-222-3306809
} 
The rare endemic Turkish species Cota fulvida (Grierson) Holub (Syn. Anthemis fulvida Grierson) was rediscovered 113 year after its first collection.

The plants of Asteraceae family have been found to be the most commonly used families in the traditional medical treatments in Turkey. Ethnomedicinal aspects of potent of Asteraceae plants have recently been reported [7]. Many genera have been approved for applying in treatment of a number of diseases, Tanacetum [8], Silybum [9], Matricaria [10], Achillea [11], Artemisia [12] and Anthemis [13]. Several aspects on chemical and pharmacological potent of the genus Anthemis have recently been reported by Siasar-Karbasky et al. [14]. A previous phytochemical studies on Anthemis species resulted with polyphenols [2, 3], mono- and sesquiterpenes and fatty acids [15]. Biological activity investigations of Anthemis species encompasses antibacterial[16], antioxidant [17], cytotoxic [18], antiproliferative [19], antidiabetic [20], antiinflammatory [21] and lipoxygenase inhibition [22] potentials. A literature search revealed information about tyrosinase inhibition potent of extract from Anthemis nobilis [23].

Recently, mostly due to the potent side effects of modern synthetic drugs and increasing contraindications to their usage, a resurgent trend has emerged towards the use of medicinal plants [24]. Today there is increasing demand for cheap, safe and scientifically approved botanicals from domestic sources. However, there are still species have not been investigated for phytochemical and biological potentials. The plants of the genus Cota are among less-investigated species. To the best of our knowledge, there is no previous information about chemical composition and biological activity of C. fulvida species.

Taking into consideration the previous literature data on chemistry and activity of Anthemis species as well as lacking information about $C$. fulvida we aimed to investigate chemical composition and biological potential of this species. Therefore, the essential oil and methanol extract of $C$. fulvida were screened for antioxidant activity using different in vitro methods like 2,2-diphenyl-1-picrylhydrazyl (DPPH) radical scavenging, Trolox equivalent antioxidant capacity (TEAC) and $\beta$-carotene bleaching tests. The antioxidant effects of $C$. fulvida oil and extract on oxidative damage were also evaluated with enzymatic test using xanthine - xanthine oxidase system that generated superoxide anion radical $\left(\mathrm{O}_{2}{ }^{-}\right)$. The test samples which interact with xanthine oxidase can affect the kinetics of xanthine oxidation to uric acid which causes hyperuricacidemia associated with gout [25]. Xanthine oxidase (XO) has a role in the generation of reactive oxygen species in various pathologies such as viral infection, inflammation, brain tumors or the process of ischemia/reperfusion. Thus, inhibitors of XO are expected to be therapeutically useful for the treatment or prophylaxis of these diseases. In literature, there is information about antidiabetic properties of Anthemis nobilis [26]. Glucoside chamaemeloside was shown to have in vivo hypoglycemic activity [27]. The investigation of inhibitory activity of $C$. fulvida against pancreatic $\alpha$-amylase, which is known as key enzyme in digestion of dietary carbohydrate in organism, may give information on antihyperglycemic potent of the plant.

In scope of the present work, we attempted to investigate the potential of $C$. fulvida against tyrosinase enzyme in vitro. Tyrosinase is the key enzyme in production of melanin [28]. The central role of tyrosinase in dopamine neurotoxicity as well as contribution to the neurodegenerative Parkinson's disease was well documented [29]. Inhibitors of tyrosinase found application in cosmetic products for whitening and depigmentation after sunburn as well as for the treatment of hyperpigmentation. Nowadays, there is increasing demand for naturally derived inhibitors of tyrosinase due to diverse side effects of synthetic products. The tyrosinase inhibitory activity of A. nobilis methanol extracts (flower, stem and root) was reported by Park et al. [23]. All these reports encouraged us to investigate $C$. fulvida for antityrosinase activity. The present research work is the first contribution into the chemistry and biological activities of C. fulvida, endemic species from Turkey.

\section{Materials and Methods}

\subsection{Reagents and Materials}

3,4-Dihydroxyl-L-phenilalanin, $\beta$-carotene, linoleic acid, Tween-20, butylated hydroxytoluene (BHT), gallic acid, ( \pm )-6-hydroxy-2,5,7,8-tetramethylchromane-2-carboxylic acid (Trolox), 2,2-diphenyl1-picrylhydrazyl (DPPH), amonium acetate, kojic acid, acarbose, 3,4-dihydroxy-L-phenylalanine (L- 
DOPA) and nordihydroguaiaretic acid (NDGA), allopurinol, $\alpha$-amylase from porcine pancreas (Type VIB, EC 3.2.1.1), tyrosinase from mushroom (EC 1.14.18.1), xanthine oxidase from bovine milk (Grade IV), lipoxidase from Glycine max (Type I-B) were purchased from Sigma-Aldrich (St. Louis, MO, USA). Starch soluble extra pure, iodine and potassium iodide were purchased from Merck (Darmstadt, Germany). Sodium phosphate, disodium phosphate, aluminum chloride, water and methanol were extra pure analytical grade. $\mathrm{A} \mathrm{C}_{8}-\mathrm{C}_{40} n$-alkane standard solution was purchased from Fluka (Buchs, Switzerland). All solvents were purchased from Sigma Aldrich (Germany) and were of analytical grade.

\subsection{Plant Material}

The aerial parts of C. fulvida were collected on Dedegöl Mountain, above Melikler pastures in Yenişarbademli (Isparta) province, on 24 August 2012, and dried under the shade. Botanical identification was performed by Dr. M. Arslan and Dr. M. U. Özbek. The voucher specimen is keep in Gazi University Herbarium under the herbarium code GAZI.

\subsection{Essential Oil Isolation}

The aerial parts of $C$. fulvida were subjected to hydrodistillation $(3 \mathrm{~h})$ to yield essential oil in Clevenger-type apparatus according to European Pharmacopeia [30]. The oil was dried over anhydrous sodium sulfate and stored in sealed vials in refrigerator $\left(4^{\circ} \mathrm{C}\right)$, until GC-FID/MS analyses and biological activity testing. The oil was dissolved in $n$-hexane $(10 \%, \mathrm{v} / \mathrm{v})$ to conduct chromatographic determination of the composition.

\subsection{Extract Preparation}

Aerial parts of $C$. fulvida were subjected to maceration in methanol with continuous shaking (3000 per min) at room temperature for $24 \mathrm{~h}$. The obtained liquid extract was filtered and evaporated until dryness in vacuo. The dried extract was kept at $4^{\circ} \mathrm{C}$ before phytochemical analysis and biological activities tests.

\subsection{Gas Chromatographic Analysis}

The oil was analyzed with GC-FID and GC/MS techniques simultaneously. Details of chromatographic analysis conditions are given in S1 (Supporting information).

\subsection{Identification and Quantification of Volatile Compounds}

Identification of the volatile constituents was given in Table 2. Identification methods are given in S2 (Supporting information)

\section{7. $L C$ - MS/MS Analysis}

LC-MS/MS analysis was carried out using an Absciex 3200 Q trap MS/MS detector. The experiment's conditions are given in S3 (Supporting information).

\subsection{Free Radical Scavenging Activity (DPPH assay)}

The free radical scavenging ability of the essential oil and the extract of $C$. fulvida were evaluated according to bleaching of purple colored methanol solution of DPPH stable radical using a method of Brand-Williams [31] with slight modifications. Details of the experiments are given in S4 (Supporting information). The free radical scavenging activity of the samples was calculated on base of triplicate experiments and expressed as percentage of inhibition calculated according to equation (1):

$$
\% \operatorname{Inh}=\left(\frac{\mathrm{Abs}_{\text {control }-\mathrm{Abs}_{\text {sample }}}}{\mathrm{Abs}_{\text {control }}}\right) \times 100,
$$


where, $A b s_{\text {control }}$ is the absorbance of the control (containing all reagents except the test compound), $A b s_{\text {sample }}$ is the absorbance of the sample with added DPPH. The $\mathrm{IC}_{50}$ values were obtained by plotting the DPPH scavenging percentage of each sample against the sample concentration. Data were analyzed using the SigmaPlot software (Version 12.0).

\subsection{Trolox Equivalent Antioxidant Capacity (TEAC assay)}

$\mathrm{ABTS}^{\cdot+}$ free radical cation scavenging activity of the essential oil and extract were tested according to the procedure described by Re et al. [32] with slight modifications. Details of the experiments are given in S5 (Supporting information). ABTS $^{++}$scavenging activity of the samples was expressed as Trolox equivalent antioxidant capacity and calculated using linear equation obtained for Trolox $(\mathrm{y}=33.644 \mathrm{x}+$ $\left.2.6523, \mathrm{r}^{2}=0.9942\right)$.

\subsection{0. $\beta$-Carotene / Linoleic Acid Peroxidation Inhibition Assay}

Inhibition of lipid peroxidation by $C$. fulvida essential oil and methanol extract was measured according to method of Marco [33] with slight modifications. $\beta$-Carotene / linoleic acid peroxidation inhibition assay uses a linoleic acid in an emulsified form (with Tween-20) as the model lipid substrate. Briefly, the method lies in between methods employing only model substrates (e.g. DPPH) and those using real lipids. Details of the experiments are given in S6 (Supporting information). The rate of $\beta$-carotene bleaching was monitored by measuring the absorbance at $15 \min$ periods at $470 \mathrm{~nm}$ sing an ELISA microplate reader (Biotek Powerwave XS) [33, 34]. The experiment was performed in triplicate and the results were expressed as average of inhibition percentage values calculated according to equation (2):

$$
\% \mathrm{AA}=\left[1-\frac{\left(\mathrm{Abs}_{\text {sample }}-\mathrm{Abs} 120_{\text {sample }}\right)}{\mathrm{Abs}_{\text {control }}-\mathrm{Abs} 120_{\text {control }}}\right] \times 100,
$$

where, AA is antioxidant activity, $A b s_{0 \text { sample }}$ and $\mathrm{A} b s_{120 \text { sample }}$ are the absorbance of the sample at 0 min and $120 \mathrm{~min}, A b s_{0 \text { control }}$ and $A b_{120 c o n t r o l}$ are the absorbance values of the control at $0 \mathrm{~min}$ and $120 \mathrm{~min}$.

\subsection{Microtiter Assay for Determination of Xanthine Oxidase Inhibition}

The xanthine oxidase inhibition assay was carried out according to procedure reported by Chen [35] with slight modifications. The stock solutions of the essential oil and the extract of $C$. fulvida (5 $\mathrm{mg} / \mathrm{mL})$ were prepared in methanol, then diluted with phosphate buffer $(0.1 \mathrm{M}, \mathrm{pH}=7.5)$ up to $1 \mathrm{mg} / \mathrm{mL}$. Details of the experiments are given in S7 (Supporting information). Absorbance at $295 \mathrm{~nm}$ was recorded with spectrophotometer. The percentage inhibition was calculated according to equation (3):

$$
\% \operatorname{Inh}=\left[\frac{\left(\mathrm{Abs}_{\text {control }}-\mathrm{Abs}_{\text {control blank }}\right)-\left(\mathrm{Abs}_{\text {sample }}-\mathrm{Abs}_{\text {sample blank }}\right)}{\mathrm{Abs}_{\mathrm{control}}-\mathrm{Abs}_{\mathrm{control}} \text { blank }}\right] \times 100
$$

where $A b s_{\text {control }}$ and $A b s_{\text {control blank }}$ are the absorbance values of the control and its blank, $A b s_{\text {sample }}$ and $A b s_{\text {sample }}$ blank are the absorbance values of the sample and its blank.

\subsection{Microtiter Assay for Determination of $\alpha$-Amylase Inhibition}

The activity of $\alpha$-amylase was measured using iodine/potassium iodide (IKI) method [36] with slight modifications. The substrate solution $(0.05 \%)$ was prepared as follow: soluble potato starch $(10 \mathrm{mg})$ was dissolved in $20 \mathrm{~mL}$ ultrapure water then boiled for $10 \mathrm{~min}$ and cooled to room temperature before use. Details of the experiments are given in S8 (Supporting information). The sample and blank absorbance values were read at $630 \mathrm{~nm}$. The percentage inhibition of the $\alpha$-amylase activity (Inh \%) was calculated according to equation (3). 


\subsection{Microtiter Assay for Determination of Lipoxygenase Inhibition}

Inhibition of lipoxygenase activity was measured with spectrophotometric method reported by Albano et al. [37] with slight modifications. The increase in absorbance at $234 \mathrm{~nm}$ was recorded for 6 min. The percentage inhibition was calculated according to equation (3). Details of the experiments are given in S9 (Supporting information).

\subsection{Microtiter Assay for Determination of Tyrosinase Inhibition}

An inhibitory activity of $C$. fulvida essential oil and methanol extract against tyrosinase was measured using the modified 96-well microplate method reported by Masuda [38]. The oil and the extract were dissolved in DMSO (10 \%) and then diluted with buffer ( $\mathrm{pH} 6.8$ ) to get concentration $1 \mathrm{mg} / \mathrm{mL}$. Details of the experiments are given in S10 (Supporting information).The percentage inhibition of the tyrosinase activity (Inh \%) was calculated according to equation (4):

$$
\operatorname{Inh} \%=\{[(A-B)-(C-D)] /(A-B)\} \times 100
$$

\subsection{Statistical Analysis of Data}

Data obtained from antioxidant and enzyme inhibition experiments were expressed as mean standard error $( \pm \mathrm{SEM})$. $\mathrm{IC}_{50}$ values were estimated using a nonlinear regression algorithm.

\section{Results and Discussion}

In literature, it could be found highlighting promising phytochemical properties and biological activities of diverse Anthemis species. However, there is no information about phytochemistry and biological potential of endemic species $C$. fulvida. The main goal of the present work was to evaluate chemical composition and biological properties of endemic C. fulvida volatile and non-volatile metabolites.

\subsection{Essential Oil Composition}

In the present work, the essential oil of Cota fulvida has been hydrodistilled and investigated for chemical profile for the first time. The hydrodistillation of the herb of $C$. fulvida resulted with yellowish essential oil ( $0.1 \%$ yield) with specific odor.

Gas-chromatographic analysis of the oil resulted with 70 compounds, which belong to diverse phytochemical groups, namely, monoterpene hydrocarbon, oxygenated monoterpene, sesquiterpene hydrocarbon, oxygenated sesquiterpene, fatty acids, aliphatic aldehydes and alkanes. The list of detected compounds with their relative retention indices, relative percentages and method of identification is given in Table 1 in order of their elution on the HP-Innowax FSC column. Gas-chromatographic profile of $C$. fulvida essential oil is presented on Figure S11 (Supporting information).

In general, the essential oil of $C$. fulvida was characterized with high abundance of the fatty acids $(>30.0 \%)$. Hexadecanoic acid $(25.6 \%)$ was found as predominate fatty acid in the oil. It is noteworthy to mark that the monoterpenes as hydrocarbons $(12.6 \%)$ and oxygenated $(15.9 \%)$ constituents were found as the second important group after fatty acids in the essential oil. Camphor $(6.1 \%), 1,8$-cineole $(4.9 \%)$ and $\alpha$-pinene $(3.0 \%)$ were the major monoterpenes in the oil. The sesquiterpenes comprised almost all of oxygenated constituents $(19.0 \%)$ with caryophyllene oxide $(5.3 \%)$, humulene epoxide $(3.9 \%)$ and spathulenol $(2.4 \%)$ as major constituents. Distribution of the main compound groups detected in the essential oil of Cota fulvida is presented on Figure S12 (see supporting information). 
Table 1. Chemical compositions of Cota fulvida herb essential oil

\begin{tabular}{|c|c|c|c|c|c|}
\hline No & RRI $^{\mathbf{a})}$ & $\mathbf{R R I}^{\mathbf{b})}$ & Compound & $\%^{\mathrm{c})}$ & ID \\
\hline 1 & 1032 & 1032 [39] & $\alpha$-Pinene & 3.0 & $\mathrm{~d}, \mathrm{e}, \mathrm{f}$ \\
\hline 2 & 1076 & $1076[39]$ & Camphene & 0.4 & $d, e, f$ \\
\hline 3 & 1118 & 1118 [39] & $\beta$-Pinene & 2.1 & $d, e, f$ \\
\hline 4 & 1188 & $1177[40]$ & $\alpha$-Terpinene & $\mathrm{t}$ & $d, e, f$ \\
\hline 5 & 1203 & $1203[39]$ & Limonene & 1.6 & $d, e, f$ \\
\hline 6 & 1213 & $1212[40]$ & 1,8-Cineole & 4.9 & $d, e, f$ \\
\hline 7 & 1244 & $1242[25]$ & Amyl furan & 0.5 & $\mathrm{~d}, \mathrm{e}, \mathrm{f}$ \\
\hline 8 & 1255 & $1256[41]$ & $\gamma$-Terpinene & 0.4 & $d, e, f$ \\
\hline 9 & 1280 & $1278[15]$ & $p$-Cymene & 0.2 & $d, e, f$ \\
\hline 10 & 1290 & $1283[42]$ & Terpinolene & $\mathrm{t}$ & $d, e, f$ \\
\hline 11 & 1348 & $1347[40]$ & 6-Methyl-5-hepten-2-one & 0.3 & $e, f$ \\
\hline 12 & 1400 & $1400[40]$ & Nonanal & 0.7 & $d, e, f$ \\
\hline 13 & 1452 & $1454[40]$ & 1-Octen-3-ol & 0.3 & $d, e, f$ \\
\hline 14 & 1474 & $1474[39]$ & trans-Sabinene hydrate & 0.1 & $d, e, f$ \\
\hline 15 & 1479 & $1458[25]$ & $(E, Z)-2,4$-Heptadienal & 0.2 & $\mathrm{~d}, \mathrm{e}, \mathrm{f}$ \\
\hline 16 & 1507 & $1475[25]$ & $(E, E)-2,4$-Heptadienal & 0.4 & $d, e, f$ \\
\hline 17 & 1509 & & Dihydroedulane & 0.5 & $e, f$ \\
\hline 18 & 1532 & $1532[40]$ & Camphor & 6.1 & $d, e, f$ \\
\hline 19 & 1548 & $1547[25]$ & (E)-2-Nonenal & $\mathrm{t}$ & $d, e, f$ \\
\hline 20 & 1553 & $1553[40]$ & Linalool & 1.0 & $d, e, f$ \\
\hline 21 & 1556 & $1556[40]$ & cis-Sabinene hydrate & 0.2 & $d, e, f$ \\
\hline 22 & 1586 & $1586[40]$ & Pinocarvone & 0.5 & $d, e, f$ \\
\hline 23 & 1611 & $1611[40]$ & Terpinen-4-ol & 2.0 & $d, e, f$ \\
\hline 24 & 1638 & $1638[40]$ & $\beta$-Cyclocitral & 0.6 & $d, e, f$ \\
\hline 25 & 1648 & $1648[40]$ & Myrtenal & 0.3 & $d, e, f$ \\
\hline 26 & 1670 & $1670[40]$ & trans-Pinocarveol & 1.0 & $d, e, f$ \\
\hline 27 & 1678 & $1678[40]$ & cis-p-Mentha-2,8-dien-1-ol & $\mathrm{t}$ & d,e,f \\
\hline 28 & 1682 & $1682[40]$ & $\delta$-Terpineol & $\mathrm{t}$ & $d, e, f$ \\
\hline 29 & 1683 & $1683[40]$ & trans-Verbenol & 0.3 & $d, e, f$ \\
\hline 30 & 1687 & $1687[39]$ & $\alpha$-Humulene & 0.4 & $d, e, f$ \\
\hline 31 & 1706 & $1706[40]$ & $\alpha$-Terpineol & 0.7 & $d, e, f$ \\
\hline 32 & 1719 & $1719[40]$ & Borneol & 0.9 & $d, e, f$ \\
\hline 33 & 1738 & $1740[40]$ & $p$-Mentha-1,5-dien-8-ol & $\mathrm{t}$ & $d, e, f$ \\
\hline 34 & 1798 & $1809[40]$ & Methyl salicylate & 0.5 & $d, e, f$ \\
\hline 35 & 1804 & $1804[40]$ & Myrtenol & 0.4 & $d, e, f$ \\
\hline 36 & 1811 & & trans- $p$-Mentha-1(7),8-dien-2-ol & $\mathrm{t}$ & $d, e, f$ \\
\hline 37 & 1827 & $1826[25]$ & $(E, E)$-2,4-Decadienal & 0.8 & d,e,f \\
\hline 38 & 1830 & $1830[40]$ & Tridecanal & 0.5 & $d, e, f$ \\
\hline 39 & 1838 & $1838[40]$ & $(E)-\beta$-Damascenone & $\mathrm{t}$ & $e, f$ \\
\hline 40 & 1845 & $1845[40]$ & trans-Carveol & 0.3 & $d, e, f$ \\
\hline 41 & 1868 & $1868[40]$ & $(E)$-Geranyl acetone & 1.3 & $d, e, f$ \\
\hline 42 & 1896 & & cis-p-Mentha-1(7),8-diene-2-ol & 0.2 & $e, f$ \\
\hline 43 & 1933 & $1933[40]$ & Tetradecanal & 0.3 & $d, e, f$ \\
\hline 44 & 1958 & $1958[40]$ & (E)- $\beta$-Ionone & 1.5 & $d, e, f$ \\
\hline 45 & 1962 & & Birkenyl acetate & 0.2 & $d, e, f$ \\
\hline 46 & 1985 & & trans- $\beta$-Ionone-5,6-epoxide & 0.5 & $e, f$ \\
\hline 47 & 2008 & 2008 [43] & Caryophyllene oxide & 5.3 & $d, e, f$ \\
\hline 48 & 2026 & $2024[40]$ & Humulene epoxide II & 3.9 & $e, f$ \\
\hline 49 & 2028 & & Caryophylla-2(12),6(13)-5-one & $\mathrm{t}$ & $d, e, f$ \\
\hline 50 & 2081 & & Humulene epoxide-III & 0.3 & $e, f$ \\
\hline 51 & 2084 & $2089[40]$ & Octanoic acid & 0.2 & $d, e, f$ \\
\hline 52 & 2144 & $2136[44]$ & Spathulenol & 2.4 & $\mathrm{~d}, \mathrm{e}, \mathrm{f}$ \\
\hline 53 & 2179 & & 3,4-Dimethyl-5-pentylidene-2 $(5 \mathrm{H})$-furanone & 0.8 & $e, f$ \\
\hline 54 & 2187 & $2187[45]$ & T-Cadinol & 0.6 & $d, e, f$ \\
\hline 55 & 2192 & $2196[40]$ & Nonanoic acid & 0.3 & $\mathrm{~d}, \mathrm{e}, \mathrm{f}$ \\
\hline
\end{tabular}




\begin{tabular}{|c|c|c|c|c|c|}
\hline No & RRI') & $\mathbf{R R I}^{\mathbf{b})}$ & Compound & $\%{ }^{c)}$ & ID \\
\hline 56 & 2206 & & Alismol $(=6,10(14)$ Guaiadien-4- $\beta$-ol $)$ & 0.2 & $e, f$ \\
\hline 57 & 2234 & & 1-Pentadecanol & 0.2 & d,e,f \\
\hline 58 & 2298 & $2296[40]$ & Decanoic acid & 0.5 & d,e,f \\
\hline 59 & 2300 & $2300[46]$ & Tricosane & 1.9 & $\mathrm{~d}, \mathrm{e}, \mathrm{f}$ \\
\hline 60 & 2316 & & Caryophylla-2(12),6(13)-dien-5 $\beta$-ol & 0.7 & d,e,f \\
\hline 61 & 2324 & $2324[39]$ & Caryophylla-2(12),6(13)-dien-5 $\alpha$-ol & 2.0 & d,e,f \\
\hline 62 & 2326 & & Eudesma-4(15),7-dien-1- $\beta$-ol & 0.2 & $\mathrm{e}, \mathrm{f}$ \\
\hline 63 & 2336 & & Farnesyl acetone & 1.1 & $\mathrm{~d}, \mathrm{e}, \mathrm{f}$ \\
\hline 64 & 2392 & 2392 [39] & Caryophylla-2(12),6-dien-5 $\beta$-ol & 2.1 & $\mathrm{~d}, \mathrm{e}, \mathrm{f}$ \\
\hline 65 & 2500 & $2500[39]$ & Pentacosane & 0.9 & $\mathrm{~d}, \mathrm{e}, \mathrm{f}$ \\
\hline 66 & 2503 & $2503[40]$ & Dodecanoic acid & 0.7 & $\mathrm{~d}, \mathrm{e}, \mathrm{f}$ \\
\hline 67 & 2617 & $2617[40]$ & Tridecanoic acid & 0.3 & $\mathrm{~d}, \mathrm{e}, \mathrm{f}$ \\
\hline 68 & 2622 & $2606[47]$ & Phytol & 0.7 & $\mathrm{~d}, \mathrm{e}, \mathrm{f}$ \\
\hline 69 & 2670 & $2670[40]$ & Tetradecanoic acid & 4.0 & $\mathrm{~d}, \mathrm{e}, \mathrm{f}$ \\
\hline \multirow[t]{2}{*}{70} & 2931 & $2931[39]$ & Hexadecanoic acid & 25.6 & $\mathrm{~d}, \mathrm{e}, \mathrm{f}$ \\
\hline & & & Total & 91.0 & \\
\hline
\end{tabular}

a) RRI: Relative Retention Indices calculated against $n$-alkanes $\left(\mathrm{C}_{8}-\mathrm{C}_{40}\right)$ on HP-Innowax column; b) RRI

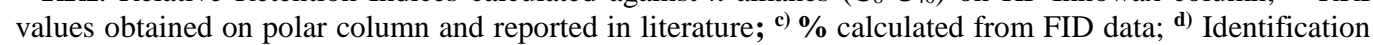
based on retention index of genuine compounds on the HP-Innowax column; ${ }^{\text {e) }}$ Identification on the basis of computer matching of the mass spectra from Başer Library; ${ }^{f)}$ Tentative identified on the basis of computer matching of the mass spectra from Adams, MassFinder, Wiley and NIST libraries; $\boldsymbol{t}$ : Trace $(<0.1 \%)$.

It was interesting to compare the chemical profile of $C$. fulvida essential oil with those reported earlier for different Anthemis species. Actually, there are several reports in the literature dealing with the essential oils of diverse Anthemis species. The fatty acids and especially hexadecanoic acid have earlier been observed to be the major constituents in previously studied essential oils obtained from aerial parts of $A$. dipsacea Bornm. (13.5\%), A. pseudocotula Boiss. (9.5\%) [48], A. altissima L. (39.6\%) [49], A. ruthenica M. Bieb. (9.9\%) and A. arvensis L. (21.2\%) [50]. Camphor was reported as main volatile constituent in $A$. cretica subsp. leucanthemoides (Boiss.) Grierson (19.4\%) [51], A. tenuisecta Ball. (17.5\%) [52], A. triumfetti (L.) DC. (15.0 \%) [53], A. hyalina DC. (11.6\%) [54] and A. pseudocotula Boiss. (9.4 \%) [55]. 1,8-Cineole was mentioned as major constituent in the oils of A. pseudocotula (39.4\%) [55], A. xylopoda O. Schwarz (16.7 \%) [56], A. widemanniana (8.9 \%) [57] and A. segetalis Ten (6.1\%) [58]. Observation of the main constituents detected in different Anthemis species, it can be concluded that the oil of $C$. fulvida was found to be similar to many Anthemis species.

Table 2. Results of LC-MS/MS analysis of Cota fulvida methanol extract.

\begin{tabular}{ccclc}
\hline Rt & [M-H] $^{-}$ & Fragments & \multicolumn{1}{c}{ Compound } & Ref. \\
\hline 7.1 & 197 & $181,167,153$ & Syringic acid & {$[59]$} \\
9.5 & 469 & $323,179,161$ & Phenylpropanoid dimer + deoxyhexose & \\
10.3 & 353 & 353,191 & 5-Feruloylquinic acid & {$[60]$} \\
11.7 & 339 & 179,161 & Caffeic acid derivative & \\
12.2 & 311 & 179,161 & Caftaric acid & {$[61]$} \\
13.0 & 609 & 301 & Quercetin rutinoside & {$[62]$} \\
14.1 & 463 & 300,271 & Quercetin glucoside & {$[63]$} \\
15.1 & 515 & $353,299,203,173$, & 3,4- $O$-Dicafeoylquinic acid & {$[63,64]$} \\
15.7 & 515 & $353,335,191,179$, & 3,5-O-Dicafeoylquinic acid & {$[63,64]$} \\
16.5 & 615 & $515,453,353,191$ & 1,5-Dicaffeoyl-3-succinoylquinic acid & {$[61]$} \\
18.9 & 473 & $311,179,161,149$ & Chicoric acids & {$[61]$} \\
21.6 & 285 & 133 & Luteolin & {$[63]$} \\
\hline
\end{tabular}

\subsection{Methanol Extract Composition}

In scope of the research, the total phenolics content and total flavonoids content of C. fulvida methanol extract were determined with Folin Ciocalteau reagent and $\mathrm{AlCl}_{3}$, respectively, via 
spectrophotometric measurements. Subsequent phytochemical analysis via LC-MS/MS technique of the extract led us to identification of phenolics acids, flavonoids and phenylpropanoid dimer. The list of the constituents detected in C. fulvida methanol extract with MS detector is summarized in Table 2.

The composition of the extract was constituted by syringic, 5-feruloylquinic, caftaric, 3,4-Odicafeoylquinic, 3,5-O-dicafeoylquinic, 1,5-dicaffeoyl-3-succinoylquinic and chicoric and caffeic acid derivative; quercetin glycosides and luteolin. Chromatographic profile of $C$. fulvida methanol extract obtained with liquid chromatography is given in Figure S13 (Supporting information).

\subsection{Antioxidant Activity}

The essential oil and methanol extract of $C$. fulvida have been investigated for an antioxidant activity by using non-enzymatic and enzymatic systems employing model substrates: stable free radical $\mathrm{DPPH}^{\circ}$ and cation radical $\mathrm{ABTS}^{+\bullet}$ as well as real substrates: linoleic acid peroxides and superoxide anion radicals $\left(\mathrm{O}_{2}{ }^{-}\right.$ -). Such approach allowed obtaining rather realistic results about antioxidant potent of the samples. According to antioxidant activity experiments, the methanol extract of $C$. fulvida demonstrated the highest antioxidant activity in all applied assays. Namely, the extract scavenged DPPH radicals with $\mathrm{IC}_{50} 0.131$ $\mathrm{mg} / \mathrm{mL}$. It was more effective than BHT $\left(\mathrm{IC}_{50} 0.50 \mathrm{mg} / \mathrm{mL}\right.$ ) but less effective than ascorbic acid $\left(\mathrm{IC}_{50} 0.03\right.$ $\mathrm{mg} / \mathrm{mL}$ ) and gallic acid $\left(\mathrm{IC}_{50} 0.003 \mathrm{mg} / \mathrm{mL}\right)$. The essential oil did not demonstrated activity in this assay. The extract prevented bleaching of $\beta$-carotene by inhibition of linoleic acid peroxidation at $36.3 \%$, while the essential oil was inactive. In the TEAC assay, the methanol extract showed ABTS ${ }^{\bullet+}$ bleaching activity equivalent to $1.33 \mathrm{mM}$ of Trolox (water soluble tocopherol), while the oil demonstrated weak activity ( 0.44 $\mathrm{mM}$ of Trolox). In the xanthine/ xanthine oxidase system, the extract demonstrated the highest inhibitory effect $(69.36 \%)$. Therefore, as can be seen from the antioxidant activity determination results (Table 2), the essential oil and the extract possess different potentials in diverse oxidation systems.

In the extract of $C$. fulvida polyphenols have been presented by phenolic acids as well as flavonoids and their glycosides. The phenolic acids in the extract comprised of 3,4-O-dicafeoylquinic, 3,5-Odicafeoylquinic, 1,5-dicaffeoyl-3-succinoylquinic, caftaric and chicoric acids. In literature there is information that caffeoylquinic acid derivatives display more potent free radical-scavenging activity than the most commonly used antioxidants (such as vitamin C, vitamin E, and caffeic acid) [65].

On the other hand, the biological activity of phenolic compounds is known to be due to the activity of nonsubstituted hydroxyl groups. In flavonoid's structure, the presence of a $\mathrm{C} 2-\mathrm{C} 3$ double bond on the ring $\mathrm{C}$, a dihydroxyl group (catechol-type) or three adjacent hydroxyl group (pyrogallol-type) on the ring $\mathrm{B}$, and the presence of C-5, and C-7 hydroxyl group on the ring A are mentioned as requirements for antioxidant activity [66, 67]. Luteolin, quercetin rutinoside and glucoside detected in the extract of $C$. fulvida have all mentioned requirements. Therefore, noteworthy antioxidant activity of the extract may be due to those compounds. In conclusion, the methanol extract of $C$. fulvida may be considered as potential antioxidant agent in preventing of oxidative damage.

\subsection{Inhibitory Effects of the Plant on Pancreatic $\alpha$-Amylase Activity}

The essential oil and methanol extract of $C$. fulvida were in vitro evaluated for hypoglycemic activity via inhibition of the pancreatic $\alpha$-amylase. As can be seen in Table 2 , both of the tested extracts demonstrated inhibitory activity. The oil inhibited the enzyme's activity up to $75.11 \%$ at concentration 0.5 $\mathrm{mg} / \mathrm{mL}$. The extract demonstrated significant inhibiton and prevented activity of $\alpha$-amylase with $\mathrm{IC}_{50} 0.35$ $\mathrm{mg} / \mathrm{mL}$. It seems to be that the plant of $C$. fulvida can be source of an effective hypoglycemic phytochemicals.

One of prominent inhibitors of $\alpha$-amylase in herbal products are the flavonoids. The molecular structures that influence the inhibition of $\alpha$-amylase by flavonoids are the following: the hydroxylation of flavonoids improved the inhibitory effect on $\alpha$-amylase; the presence of an unsaturated 2,3-bond in conjugation with a 4-carbonyl group has been associated with stronger inhibition [67]. The methanol extract of $C$. fulvida contained flavonoid aglycone as well as flavonoid glycosides. Walle et al. reported that the 
glycosylation of flavonoids decreased the inhibitory effect on $\alpha$-amylase depending on the conjugation site and the class of sugar moiety [68].

\subsection{Inhibitory Effects of the Plant on Lipoxygenase Activity}

Antiinflammatory effect of C. fulvida was tested in 5-LOX enzyme inhibition system. Actually, 5lipoxygenase catalyzes the oxidation of arachidonic acid and produces 5(S)-hydroxyperoxyeicosatetraenoic acid (5-HETE) which undergoes dehydration, resulting in the formation of leukotriene. Enzymatic hydrolysis of leukotriene, as well as conjugation with other substances, leads to the formation of inflammatory mediators. In the present study, the oil and extract of $C$. fulvida were found to be able to inhibit 5-lipoxygenase, particularly the oil (Inh $53.67 \%$ at $1 \mathrm{mg} / \mathrm{mL}$ ), in comparison to the extract (Inh $23.91 \%$ at $5 \mathrm{mg} / \mathrm{mL}$ ) which showed poor activity (Table 2 ).

\subsection{Inhibitory Effects of the Plant on Mushroom Tyrosinase Activity}

In this experiment, tyrosinase inhibitory effects of $C$. fulvida oil and extract on diphenolase activity of mushroom tyrosinase were evaluated. The extract demonstrated the highest inhibitory activity (45.46 $\%$ ). However, the oil was found inactive when tested at a concentration $1 \mathrm{mg} / \mathrm{mL}$ (Table 3). In general, it can be assumed that $C$. fulvida have moderate antityrosinase effect.

Table 3. The biological activity of $C$. fulvida essential oil and extract ${ }^{\S}$

\begin{tabular}{|c|c|c|c|c|c|c|c|c|c|}
\hline Sample & $\begin{array}{l}\text { DPPH, } \\
\text { IC }_{50}\end{array}$ & $\begin{array}{c}\beta \text {-Carotene } \\
\text { bleachinga), } \\
\% \text { Inh }\end{array}$ & $\begin{array}{l}\text { TEA } \\
\text { Ca), } \\
\text { mM }\end{array}$ & $\begin{array}{l}\text { XOD, } \\
\% \text { Inh }\end{array}$ & $\begin{array}{c}\text { TPC, } \\
\text { GAE } \\
\text { mg/mL }\end{array}$ & $\begin{array}{l}\text { TFC, QE } \\
\mathrm{mg} / \mathrm{mL}\end{array}$ & $\begin{array}{c}\alpha- \\
\text { Amylase }^{b)}, \\
\% \text { Inh }\end{array}$ & $\begin{array}{l}\text { LOX } \\
\text { \%Inh }\end{array}$ & $\begin{array}{l}\text { Tyro }{ }^{\mathrm{c}} \text {, } \\
\% \text { Inh }\end{array}$ \\
\hline Essential oil & N/A & N/A & 0.44 & 1.87 & - & - & 75.11 & 53.67 & N/A \\
\hline $\begin{array}{l}\text { Methanol } \\
\text { extract }\end{array}$ & 0.131 & 36.31 & 1.33 & 69.36 & 0.294 & 0.046 & 0.350 & 23.91 & 45.46 \\
\hline Gallic acid & 0.003 & - & - & - & - & - & - & - & - \\
\hline Ascorbic acid & 0.03 & - & - & - & - & - & - & - & - \\
\hline BHT & 0.50 & 85.0 & - & - & - & - & - & - & - \\
\hline Acarbose & - & - & - & - & - & - & 98 & - & - \\
\hline NDGA & - & - & - & - & - & - & - & 86.0 & - \\
\hline Allopurinol & - & - & - & 81.00 & - & - & - & - & - \\
\hline Kojic acid & - & - & - & - & - & - & - & - & 84 \\
\hline \multicolumn{10}{|c|}{$\begin{array}{l}\text { BHT: butylated hydroxytoluene; N/A: not active; NDGA: nordihydroguaiaretic acid; }{ }^{\S} \text { the deviation from the mean is }<\% 10 \text { of the mean value; } \\
\text { a) Concentration of sample } 5 \mathrm{mg} / \mathrm{mL} ;{ }^{\text {b) }} \text { Concentration of sample } 0.5 \mathrm{mg} / \mathrm{mL} ;{ }^{\text {c) }} \text { Concentration of sample } 1 \mathrm{mg} / \mathrm{mL}\end{array}$} \\
\hline
\end{tabular}

As a conlusion, we herein disclose the first report on chemical profile of the volatile and non-volatile secondary metabolites obtained from endemic species $C$. fulvida. This species can be considered as source of valuable metabolites: the oil is rich with diverse mono- and sesquiterpenes, and fatty acids, while the extract contained phenolic acids, flavonoids and phenylpropanoids. In scope of the present study, the biological potential of volatile and non-volatile fractions of $C$. fulvida was evaluated for the first time. It seems, that $C$. fulvida can be considered as valuable source of bioactive components useful in combating various diseases such as cell damage, inflammation, skin disease, neurodegenerative problems as well as in the provision of cheap, safe and natural phytoparmaceuticals.

\section{Disclosure statement}

The authors declare that there are no conflicts of interest. 


\section{Acknowledgments}

Authors are gratefully thanks to Anadolu University Scientific Research Department for supporting this research project (BAP №1705S171) and to the Research Institute for Forest Soil and Ecology (Eskisehir) for their support in fieldwork.

\section{Supporting Information}

Supporting information accompanies this paper on http://www.acgpubs.org/journal/records-ofnatural-products

\section{ORCID}

Gulmira Özek: 0000-0001-8908-6098

M. Ufuk Özbek: 0000-0002-2342-4143

Süleyman Yur: 0000-0001-5980-4992

Fatih Göger: 0000-0002-9665-0256

Munevver Arslan: 0000-0003-2645-1486

Temel Özek: $\underline{0000-0003-4251-8783}$

\section{References}

[1] M.U. Özbek, F. Özbek, B. Başer, E. Cabi and M. Vural (2016). Pollen morphology of the genus Cota J. Gay (Asteraceae) in Turkey, Bot. Let. 163(4), 435-448.

[2] A.J.C. Grierson and Z. Yavin (1975). Anthemis L. In: P.H. Davis (ed.), Flora of Turkey and the East Aegean Islands, Vol. 5, Edinburgh, UK: Edinburgh University Press, 174-221..

[3] W. Greuter, C.H. Oberprieler and R. Vogt (2003). The Euro-Med treatment of Anthemideae (Compositae)generic concepts and required new names, Willdenowia 33(1), 40-41.

[4] R.M. Lo Presti, S. Oppolzer and C.H. Oberprieler (2010). A molecular phylogeny and a revised classification of the Mediterranean genus Anthemis s.l. (Compositae, Anthemideae) based on three molecular markers and micromorphological characters, Taxon 59(5), 1441-1456.

[5] M.U. Özbek (2012). Cota J. Gay. In: A. Güner, S. Aslan, T. Ekim, M. Vural and M.T. Babaç (eds.), Türkiye Bitkileri Listesi (Damarlı Bitkiler) [A Checklist of the Flora of Turkey (Vascular Plants)], Nezahat Gökyiğit Botanical Garden and Floristic Research Society Publication, İstanbul, 146-148.

[6] M.U. Özbek, M. Vural and R. Daskin (2011). A new species of the genus Cota (Asteraceae) from Uludag, Turkey, Turk. J. Bot. 35(4), 331-336.

[7] E. Altundag and M. Ozturk (2011). Ethnomedicinal studies on the plant resources of east Anatolia, Turkey, Proc. Soc. Behav. Sci. 19, 756-777.

[8] A. Pareek, M. Suthar, G.S. Rathore and V. Bansal (2011). Feverfew (Tanacetum parthenium L.): A systematic review, Pharm. Rev. 5(9), 103.

[9] T. Kumar, Y. Larokar, S.K. Iyer, A. Kumar and D.K. Tripathi (2017). Phytochemistry and pharmacological activities of Silybum marianum: a review, Int. J. Pharm. Phytopharm. Res. 1(3), 124-133.

[10] V. Gupta, P. Mittal, P. Bansal, S.L. Khokra and D. Kaushik (2010). Pharmacological potential of Matricaria recutita-A review, Int. J. Pharm. Sci. Drug Res. 2(1), 12-16.

[11] W.L. Applequist and D.E. Moerman (2011). Yarrow (Achillea millefolium L.): A neglected panacea? A review of ethnobotany, bioactivity, and biomedical research, Econ. Bot. 65(2), 209-225

[12] D. Obolskiy, I. Pischel, B. Feistel, N. Glotov and M. Heinrich (2011). Artemisia dracunculus 1.(tarragon): A critical review of its traditional use, chemical composition, pharmacology, and safety, J. Agric. Food Chem. 59(21), 11367-11384.

[13] A.E. Al-Snafi (2016 ). Medical importance of Anthemis nobilis (Chamaemelum nobile)- a review, As. J. Pharm. Sci. Technol. 6(2), 89-95.

[14] M. Siasar-Karbasky, M. Tehranipour and K. Nejad-Shahrokhabadi (2017). Neuroprotective effect of nbutanol, ethylacetate, aqueous and hydro-alcoholic fractions of Anthemis nobilis extracts through NGF gene expression after sciatic nerve injury in rats, J. Gorgan Univ. Med. Sci. 18(4), 49-54. 
[15] A. Maggio, L. Riccobono, V. Spadaro, A. Scialabba, M. Bruno and F. Senatore (2014). Chemical composition of the essential oils of three endemic species of Anthemis Sect. Hiorthia (DC.) R. Fern. growing wild in Sicily and chemotaxonomic volatile markers of the genus Anthemis L.: an update, Chem. Biodivers. 11(4), 652-672.

[16] G.G. Toplan, M. Tuysuz, A. Mat and G. Sariyar (2017). Antibacterial activity of Anthemis tricolor Boiss. from Cyprus, Planta Med. Int. Open. 4(S 01), Tu-PO-149.

[17] N. Stojkovic, M. Stojkovic, M. Marinkovic, G. Chopra, D. Kostic and A. Zarubica (2014). Polyphenol content and antioxidant activity of Anthemis cretica L. (Asteraceae), Oxid. Commun. 37(1), 237-246.

[18] A.R. Jassbi, O. Firuzi, R. Miri, S. Salhei, S. Zare, M. Zare, M. Masroorbabanari, J.N. Chandran, B. Schneider and I.T. Baldwin (2016). Cytotoxic activity and chemical constituents of Anthemis mirheydari, Pharm. Biol. 54(10), 2044-2049.

[19] S.K. Bardaweel, K.A. Tawaha and M.M. Hudaib (2014). Antioxidant, antimicrobial and antiproliferative activities of Anthemis palestina essential oil, BMC Compl. Altern. Med. 14(1), 297-305.

[20] F.U. Afifi and V. Kasabri (2013). Pharmacological and phytochemical appraisal of selected medicinal plants from Jordan with claimed antidiabetic activities, Sci. Pharm. 81(4), 889-932.

[21] S. Özkaynak, H.E. Kolatan, O. Yilmaz and B. Kivcak (2011). Anti-inflammatory activity of Anthemis aciphylla var. aciphylla Boiss, Turk. J. Biol. 35(6), 757-762.

[22] A. Wei and T. Shibamoto (2010). Antioxidant/lipoxygenase inhibitory activities and chemical compositions of selected essential oils, J. Agric. Food Chem. 58(12), 7218-7225.

[23] H.-W. Park, K.-H. Jang, M. Hussain and D.-J. Lee (2012). Evaluation of 1, 1-diphenyl-2-picrylhydrazyl radical scavenging effect, cytotoxicity and tyrosinase inhibition activities in 4 species of herb plants, J. Appl. Biol. Chem. 55(4), 201-205.

[24] R.D.E. Sewell and M. Rafieian-Kopaei (2014). The history and ups and downs of herbal medicine usage, $J$. HerbMed. Pharmacol. 3(1), 1-3.

[25] S. Song, X. Zhang, K. Hayat, Z. Xiao, Y. Niu and K. Eric (2013). Coordinating fingerprint determination of solid-phase microextraction/gas chromatography-mass spectrometry and chemometric methods for quality control of oxidized tallow, J. Chrom. A. 1278, 145-152.

[26] M. Eddouks, A. Lemhadri, N.A. Zeggwagh and J.B. Michel (2005). Potent hypoglycaemic activity of the aqueous extract of Chamaemelum nobile in normal and streptozotocin -induced diabetic rats, Diabetes Res. Clin. Pract. 67(3), 189-195.

[27] G.M. Konig, A.D. Wright and W.J. Keller (1998). Hypoglycaemic activity of HMG-containing flavonoid glucoside, chamaenmeloside, from Chamaemelum nobile, Planta Med. 64, 612-614.

[28] K. Tsukamoto, I.J. Jackson, K. Urabe, P.M. Montague and V.J. Hearing (1992). A second tyrosinase- related protein, TRP- 2, is a melanogenic enzyme termed DOPAchrome tautomerase, EMBO J. 11(2), 519-526.

[29] Y. Xu, A.H. Stokes, W.M. Freeman, S.C. Kumer, B.A. Vogt and K.E. Vrana (1997). Tyrosine mRNA is expressed in human substantia nigra, Mol. Brain Res. 45(1), 159-162.

[30] EDQM and C.o. Europe (2017). Determination of Essential Oils in Herbal Drugs, 2.8.12. 9th ed. European Pharmacopoeia. European Directorate for the Quality of Medicines and Healthcare. Strasbourg: 285-286.

[31] W. Brand-Williams, M.E. Cuvelier and C.L.W.T. Berset (1995). Use of a free radical method to evaluate antioxidant activity, LWT-Food Sci. Technol. 28(1), 25-30.

[32] R. Re, N. Pellegrini, A. Proteggente, A. Pannala, M. Yang and C. Rice-Evans (1999). Antioxidant activity applying an improved ABTS radical cation decolorization assay, Free Rad. Biol. Med. 26(9), 1231-1237.

[33] G.J. Marco (1968). A rapid method for evaluation of antioxidants, J. Am. Oil Chem. Soc. 45(9), 594-598.

[34] M. Koşar, F. Göger and K.H.C. Başer (2011). In vitro antioxidant properties and phenolic composition of Salvia halophila Hedge from Turkey, Food Chem. 129(2), 374-379.

[35] C.-H. Chen, H.-C. Chan, Y.-T. Chu, H.-Y. Ho, P.-Y. Chen, T.-H. Lee and C.-K. Lee (2009). Antioxidant activity of some plant extracts towards xanthine oxidase, lipoxygenase and tyrosinase, Molecules 14(8), 2947-2958.

[36] X.W. Yang, M.Z. Huang, Y.S. Jin, L.N. Sun, Y. Song and H.S. Chen (2012). Phenolics from Bidens bipinnata and their amylase inhibitory properties, Fitoterapia 83(7), 1169-1175.

[37] S.M. Albano, A.S. Lima, L.G. Pedro, M.G. Miguel, J.G. Barroso and A.C. Figueiredo (2012). Antioxidant, anti-5-lipoxygenase and antiacetylcholinesterase activities of essential oils and decoction waters of some aromatic plants, Rec. Nat. Prod. 6(1), 35-48.

[38] T. Masuda, D. Yamashita, Y. Takeda and S. Yonemori (2005). Screening for tyrosinase inhibitors among extracts of seashore plants and identification of potent inhibitors from Garcinia subelliptica, Biosci., Biotechnol. Biochem. 69(1), 197-201.

[39] H. Noorizadeh, A. Farmany and M. Noorizadeh (2011). Application of GA-PLS and GA-KPLS calculations for the prediction of the retention indices of essential oils, Química Nova. 34(8), 1398-1404. 
[40] V.I. Babushok, P.J. Linstrom and I.G. Zenkevich (2011). Retention indices for frequently reported compounds of plant essential oils, J. Phys. Chem. Ref. Data. 40(4), 043101-043147.

[41] A. Maggio, S. Rosselli, M. Bruno, V. Spadaro, F.M. Raimondo and F. Senatore (2012). Chemical composition of essential oil from Italian populations of Artemisia alba Turra (Asteraceae), Molecules 17(9), 10232-10241.

[42] A. Orav (2001). Identification of terpenes by gas chromatography-mass spectrometry. Current Practice of Gas Chromatography-Mass Spectrometry. CRC Press.

[43] E. Mancini, L.D. Martino, A. Marandino, M.R. Scognamiglio and V.D. Feo (2011). Chemical composition and possible in vitro phytotoxic activity of Helichrsyum italicum (Roth) Don ssp. italicum, Molecules 16(9), 7725-7735.

[44] J.J. Brophy, R.J. Goldsack, A. Punruckvong, A.R. Bean, P.I. Forster, B.J. Lepschi, J.C. Doran and A.C. Rozefelds (2000). Leaf essential oils of the genus Leptospermum (Myrtaceae) in eastern Australia. Part 7. Leptospermum petersonii, L. liversidgei and allies, Flavour Fragr. J. 15(5), 342-351.

[45] M.B. Sghaier, I. Chraief, I. Skandrani, I. Bouhlel, J. Boubaker, S. Kilani, A. Neffati, A. Mahmoud, M. Hammami and L. Chekir- Ghedira (2007). Chemical composition and antimicrobial activity of the essential oil of Teucrium ramosissimum (Lamiaceae), Chem. Biodivers. 4(7), 1480-1486.

[46] H. Noorizadeh and A. Farmany (2010). Exploration of linear and nonlinear modeling techniques to predict of retention index of essential oils, J. Chinese Chem. Soc. 57(6), 1268-1277.

[47] J. Palá-Paúl, J. Brophy, R. Goldsack and B. Fontaniella (2004). Analysis of the volatile components of Lavandula canariensis (L.) Mill., a Canary Islands endemic species, growing in Australia, Biochem. Syst. Ecol. 32(1), 55-62.

[48] A. Kurtulmus, T. Fafal, T. Mert, H. Saglam, B. Kivcak, T. Ozturk, B. Demirci and K. Baser (2009). Chemical composition and antimicrobial activity of the essential oils of three Anthemis species from Turkey, Chem. Nat. Comp. 45(6), 900-904.

[49] K. Javidnia, R. Miri, M. Kamalinejad, H. Sarkarzadeh and A. Jamalian (2004). Chemical composition of the essential oils of Anthemis altissima L. grown in Iran, Flavour Fragr. J. 19(3), 213-216.

[50] L. Vujisić, I. Vučković, V. Tešević, D. Đoković, M. Ristić, P. Janaćković and S. Milosavljević (2006). Comparative examination of the essential oils of Anthemis ruthenica and A. arvensis wild- growing in Serbia, Flavour Fragr. J. 21(3), 458-461.

[51] K.H.C. Başer, T. Özek, F. Demirci and İ. Boydağ (2002). The essential oil of Antltemis cretica L. subsp. leucanthemoides (Boiss.) Grierson, Acta Pharm. Sci. 44(3), 189-194.

[52] E.F. Hanbali, F. Mellouki, M. Akssira and B. MA (2007). Composition and antimicrobial activity of essential oil of Anthemis tenuisecta ball, J. Essent. Oil Bear. Plant. 10(6), 499-503.

[53] M. Pavlović, N. Kovačević, O. Tzakou and M. Couladis (2006). Essential oil composition of Anthemis triumfetti (L.) DC, Flavour Fragr. J. 21(2), 297-299.

[54] S.E. Sajjadi and I. Mehregan (2006). Volatile constituents of flowers and leaves of Anthemis hyalina, Chem. Nat. Compd. 42(5), 531-533.

[55] O. Kilic, A. Kocak and E. Bagci (2011). Composition of the volatile oils of two Anthemis L. taxa from Turkey, Z. Naturforschung C. 66(11-12), 535-540.

[56] A. Uzel, A. Guvensen and E. Cetin (2004). Chemical composition and antimicrobial activity of the essential oils of Anthemis xylopoda O. Schwarz from Turkey, J. Ethnopharm. 95(2), 151-154.

[57] B. Kivcak, T. Mert, H. Saglam, T. Ozturk, M. Kurkcuoglu and K. Baser (2007). Chemical composition and antimicrobial activity of the essential oil of Anthemis wiedemanniana from Turkey, Chem. Nat. Compd. 43(1), 47-51.

[58] N.S. Radulović, P.D. Blagojević, B.K. Zlatković and R.M. Palić (2009). Chemotaxonomically important volatiles of the genus Anthemis L.-a detailed GC and GC/MS analyses of Anthemis segetalis Ten. from Montenegro, J. Chin. Chem. Soc. 56(3), 642-652.

[59] I. Borrás-Linares, Z. Stojanović, R. Quirantes-Piné, D. Arráez-Román, J. Švarc-Gajić, A. FernándezGutiérrez and A. Segura-Carretero (2014). Rosmarinus officinalis leaves as a natural source of bioactive compounds, Int. J. Molec. Sci. 15(11), 20585-20606.

[60] M.N. Clifford, K.L. Johnston, S. Knight and N. Kuhnert (2003). Hierarchical scheme for LC-MS n identification of chlorogenic acids, J. Agric. Food Chem. 51(10), 2900-2911.

[61] R. Jaiswal, J. Kiprotich and N. Kuhnert (2011). Determination of the hydroxycinnamate profile of 12 members of the Asteraceae family, Phytochemistry 72(8), 781-790.

[62] V. Spínola, J. Pinto and P.C. Castilho (2015). Identification and quantification of phenolic compounds of selected fruits from Madeira Island by HPLC-DAD-ESI-MSn and screening for their antioxidant activity, Food Chem. 173, 14-30. 
[63] J.-P. Lai, Y.H. Lim, J. Su, H.M. Shen and C.N. Ong (2007). Identification and characterization of major flavonoids and caffeoylquinic acids in three Compositae plants by LC/DAD-APCI/MS, J. Chrom. B. 848(2), 215-225.

[64] M.N. Clifford, S. Knight and N. Kuhnert (2005). Discriminating between the six isomers of dicaffeoylquinic acid by LC-MS, J. Agric. Food Chem. 53(10), 3821-3832.

[65] K. Matsushige, P. Basnet, S. Kadota and T. Namba (1996). Potent free radical scavenging activity of dicaffeoyl quinic acid derivatives from propolis, J. Trad. Med. 13, 217-228.

[66] O.L. Woodman, W.F. Meeker and M. Boujaoude (2005). Vasorelaxant and antioxidant activity of flavonols and flavones: Structure activity relationships, J. CardioVasc. Pharm. 46, 302-309.

[67] J. Xiao, X. Ni, G. Kai and X. Chen (2013). A review on structure-activity relationship of dietary polyphenols inhibiting $\alpha$-amylase, Crit. Rev. Food Sci. Nutr. 53(5), 497-506.

[68] T. Walle (2004). Absorption and metabolism of flavonoids, Free Rad. Biol. Med. 36(7), 829-837.

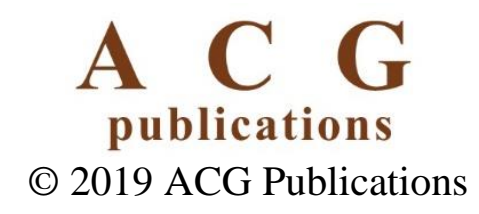

